\title{
Impact of Service Quality of Short Messaging Service on Customers Retention; an Empirical Study of Cellular Companies of Pakistan
}

\author{
Zulfqar Ahmad \\ Assistant Professor: Hailey College of Commerce, University of the Punjab, Pakistan \\ Ishfaq Ahmed (Corresponding author) \\ Lecturer: Hailey College of Commerce, University of the Punjab, Pakistan \\ E-mail: ishfakahmed@gmail.com \\ Muhammad Musarrat Nawaz \\ Lecturer: Hailey College of Commerce, University of the Punjab, Pakistan \\ Ahmad Usman \\ Lecturer: Hailey College of Commerce, University of the Punjab, Pakistan \\ Muhammad Zeeshan Shaukat \\ Lecturer: Hailey College of Commerce, University of the Punjab, Pakistan \\ Naveed Ahmad \\ Lecturer: Hailey College of Commerce, University of the Punjab, Pakistan
}

\begin{abstract}
The long term success of organizations depends on many factors. In order to survive, service sector organizations need to offer quality in service. These companies try to retain their customers by providing them quality services. The following study examines the service quality of the mobile service providers and retention intentions of the customers' with the quality offered. The study focuses only on SMS service provided by telecom organizations. Service quality is measured using 5 dimensions tangibles, empathy, assurance, responsiveness and reliability and relationship is determined with customer retention. The data was collected from 331 university students using Short Messaging Service (SMS) of any cellular company. Correlation and regression analysis are used to analyze the data. Results and discussions are presented.
\end{abstract}

Keywords: Service quality, Customer retention, Telecom sector

\section{Introduction}

Organizations are striving to be the market leader. But to be the market leader firms have to be competitive. In order to be competitive firms adopt all strategies that might bring positive change and can offer higher returns. Out of the drivers for success customers are considered to be the king. Organizations now strive to retain their customers rather than to create new ones, because retaining customers is less costly and at the same time present customers can create more customers with their word of mouth marketing.

Retaining customers is concern for all manufacturing and services sector organizations; similarly this concept is not bounded to any specific area. Telecom sector is one of the major sectors in services industry having great amount of contribution for public and state. In Pakistan telecom sector is considered to be one of the most developed sectors of economy. This sector contributes a significantly in overall GDP of the country. This sector has seen a great development in near past. The growth rate shows that number of subscribers has increased from 68,000 in 1996 to 3.3 million by end-2003; since then the subscriber base has heaved to reach 80 million in early 
2007 and exceed 95 million in 2009 (PTA). Cellular growth time period in Pakistan which lasted for almost five years (2003-2008), broke almost all global records from network coverage to number of subscriber. As Valdecantos (2009) noted the mobile telephone market of Pakistan has been experiencing 100\% sustainable growth rate for some years now. Now there is stiff competition between firms as rapid growth has lead to saturation in major markets in the world. Now firms strive to retain their customers as it is demand of time and it is cost effective as well.

This growing industry has not only attracted the business community, but also academic researchers. Numbers of studies have been conducted in cellular industry in different countries, ranging from engineering to marketing aspects of cellular services industry. Many researchers have linked consumer retention with sustainable financial performance for instance Fornell and Wernerfelt, (1987); Reichheld and Sasser, (1990). Steenkamp (1989) has viewed customer retention as one of the factor that can increase market share. Yankee Group indicated that mobile operators approximate the cost of acquiring a new client at seven times more than the annual cost of retaining an existing subscriber on an average basis.

This study is conducted to see impact of quality of service provided by telecom sector in Pakistan and its impact on intentions of customers to retain client server relation. Only SMS (Short Messaging Service) has been used to see whether there is impact of service quality on customers' intentions to use and stay.

\section{Literature Review}

Quality is the overall experience which a customer perceives through interacting a product and services. Parasuraman et al. (1988) has captured the definition of quality as taken as a whole a judgment. "Service quality has been described as a form of attitude, related but not equivalent to satisfaction that results from the comparison of expectations with performance" (Bolton and Drew, 1991; Cronin Jr. and Taylor, 1992; Parasuraman et al. 1988; and Shepherd, 1999). Quality had a long term impact on the satisfaction of customers (Omachanu et al. 2008). Atalik \& Arslan (2009) found that creating value and offering quality of service offered to customer creates loyal customers.

Customers' retention has received a lot of attention from researchers. Various researchers have given numerous promises of customers' retention. Fornell and Wernerfelt, (1987); Reichheld and Sasser, (1990) found that customers retention reduces costs and can be source of high market share. Henkel et al. (2006) found satisfied customers of telecom sector have high extent of usage and intentions to repurchase in future. Cronin et al. (2000) found that service quality, service value, and satisfaction are all directly to customers intentions of usage. Steenkamp (1989) mentioned quality as aid that retains the customer which assists to uphold share in the market likewise Fornell (1992) acknowledged satisfaction with service facilitate to retain customers.

Service quality is usually regarded as the customer's impression of the relative inferiority/superiority of a service provider and its services (Bitner \& Hubert 1994, Tsoukatos \& Rand 2006). Chau \& Kao (2009) further found that service dimensions can be argued to impact customer's evaluation of the service provider and his intentions to select the service provider. Kandampully (1998) says that Service loyalty of firms leads to loyal customers. Customers' loyalty and trust is gained by service provider's commitment to provision of services, quality of services. Kim et al. (2004) found that better quality services create customers satisfaction and ultimately creates loyal customers for future. Loyal customers are reported to have higher customer retention rates, commit a higher share of their category spending to the firm, and are more likely to recommend others to become customers of the firm. (Zeithaml, 2000, "Keiningham, et al. 2007). Chen (2008) says that perceived value of service and satisfaction with the service has significant positive effect on behavioral intentions of usage in future. Cronin et al. (2000) found that service quality, service value, and satisfaction are all directly to customers intentions of usage. Cöner and Güngör (2002) found the quality of service would leads to more loyal customer. Lai (2004) in his research in Singapore found a positive relationship between service quality and customer satisfaction and retention. Canadian scholar Barnes (1997) emphasize that loyal customer would keep recommending to others which helps the organization to earn more customers.

Kim et al. (2004) found that call quality, value added services and customer support play a significant role in building customer satisfaction for cellular service subscribers and they tend to keep using current service as the level of the customer satisfaction is high that leads to customer loyalty. Deng et al (n.d.) argues that out of the contributories of customers satisfaction perceived service quality is significant determinant of customer satisfaction and customer satisfaction enhances customer loyalty along with trust and switching cost.

There are five specific dimensions of service quality: tangibles, reliability, responsiveness, assurance and empathy (Parasuraman et al. 1988). Cavana et al. (2007) says that there are five dimensions of quality Assurance, 
Responsiveness, Empathy, Reliability and Convenience; these dimensions are considered as significantly for quality concept.

(Baumann et al. 2006) found that affective attitude, empathy and customer satisfaction leads the customers towards further recommendation to other users. Responsiveness leads to short term retention while affective attitude and empathy has long term impact on customers' satisfaction and retention. Cavana et al. (2007) found that assurance, responsiveness, empathy have strong relation with service quality, similarly, but reliability and convenience were found to be relevant but not highly significant. It is evident that in order to retain customers, customers should be satisfied through service quality (Brown \& Gulycz, 2001). Lai (2004) found positive relationship between tangibles, empathy and assurance and customers' satisfaction. Same findings were given by Cronin and Taylor (1992) in their research.

On the basis of above given literature following model and hypothesis can be drawn

\section{INSERT FIGURE 1}

\section{Hypothesis of the study}

$\mathrm{H}_{1} \quad$ There is positive relationship between service quality and Customers' Retention

H2 Tangibles are positively related with the Customers' Retention

H3 Empathy is positively correlated with the Customers' Retention

H4 Assurance is positively correlated to Customers' Retention

H5 Responsiveness is positively correlated to Customers' Retention

H6 Reliability is positively related with the customers' Retention

\section{Research Design}

\subsection{Sample}

In Pakistan youth is the biggest market for cellular companies. This study was also conducted on the youth and that part of youth that is in university education. The reason behind selection of university youth as sample is because it covers individuals covering major portion of mobile users and university students cover majority of youth and they are more vigilant and have great attraction for change and to retain these customers is difficult one. Youth pay more attention towards promotional advertisements of telecom companies. 400 students were selected from different universities and surveys questionnaire were personally administered. 331 questionnaires were received back with a response rate of $82.75 \%$. There were $60 \%$ male students and $40 \%$ female respondents with an average age of 21.60 years.

\subsection{Instrument and Measurement}

To operationalize and measure the dimensions of customers' satisfaction the instrument was adopted from the research work of Lai (2004). It includes five dimensions of Tangibles, Responsiveness, Reliability, Empathy, and Assurance. Instrument used to measure Retention was adopted from $\mathrm{Yu}$ et al. (2005). The survey questionnaire contained 23 questions, items including the personal demographics of the respondents like gender, age, area of belongingness, qualification where as remaining items were measured on 7 point Likert Scale.

\subsection{Data analysis}

The research was conducted to measure the customers' retentions regarding SMS in cellular companies of Pakistan. The Primary data was collected from the university students. SPSS 17.0 version was used for analysis.

\section{Findings and Conclusion}

The results regarding the issue are as follows.

\section{INSERT TABLE 1 HERE}

Table 1 shows mean scores and standard deviation for overall service quality and its dimensions. The mean score and standard deviation of Retention is also given. The instrument used for data collection comprised 7 point likert scale ranging from strongly disagrees to strongly agree. The mean score for service quality is 4.828 which indicate that respondents are slightly agree with the service quality of their SMS service providers. The scores on dimensions of service quality indicate that respondents are more satisfied on the 'tangibles' and 'responsiveness', moderately satisfied with two dimensions assurance and reliability, and less satisfied on the dimension 'empathy'. The Retention intentions have a mean score 5.3369 which indicates that overall people are slightly 
satisfied from their SMS service providers. The correlation between service quality and its dimensions is given below:

\section{INSERT TABLE 2 HERE}

Results of Pearson Correlation are shown in Table 2. The table indicates the relationship between the overall services quality and customer's intentions to retain. The table also shows the relationship between the five dimensions of service quality with the retention.

The results indicate that the overall service quality has a significant relationship with the customer retention $(\mathrm{r}=0.394, \mathrm{p}<0.01)$. This particular finding confirms the hypothesis $\mathrm{H} 1$ that the service quality has a positive and significant relationship with the customer retention. The dimension 'tangibles' also shows a positive and significant relationship with the customer retention $(\mathrm{r}=0.190, \mathrm{p}<0.01)$. This particular finding confirms the hypothesis $\mathrm{H} 2$ that tangibles have a positive and significant relationship with the customer retention. The dimension 'empathy' has surprisingly shown a negative and significant relationship with the customer retention $(\mathrm{r}=-0.248, \mathrm{p}<0.01)$. This particular finding does not confirm the hypothesis $\mathrm{H} 3$ that empathy has a positive and significant relationship with the customer satisfaction. The dimension 'assurance' also shows a positive and significant relationship with the customer retention $(\mathrm{r}=0.359, \mathrm{p}<0.01)$. This particular finding confirms the hypothesis $\mathrm{H} 4$ that assurance has a positive and significant relationship with the customer retention. The dimension 'responsiveness' also shows a positive and significant relationship with the customer retention $(\mathrm{r}=0.381, \mathrm{p}<0.01)$. This particular finding confirms the hypothesis H5 that responsiveness has a positive and significant relationship with the customer retention. The dimension 'reliability' also shows a positive and significant relationship with the customer retention $(\mathrm{r}=0.297, \mathrm{p}<0.01)$. This particular finding confirms the hypothesis $\mathrm{H} 6$ that reliability has a positive and significant relationship with the customer retention.

The stepwise regression was run to find out that whether the service quality is a predictor of the satisfaction of the customers. The results are shown in table 3.

\section{INSERT TABLE 3 HERE}

Table 3 explains that a relatively low percentage of the variation in satisfaction is explained by the variables entered in the equation ( $\mathrm{R}$-squared $=15.6 \%$, Adjusted R-squared $=15.3 \%$ ). Thus $15 \%$ variation in the satisfaction is explained by the service quality which is measured here using 5 dimensions. The $\mathrm{F}$ ratio is statistically significant as shown by the table 3 . The other scores are given within table 4 .

\section{INSERT TABLE 4 HERE}

\section{Discussions}

The scores indicate that customers are slightly satisfied from the service quality of SMS service providers where tangibles and assurance score more than other dimensions but empathy has the lowest score. At the same time the correlations show that dimension empathy is negatively related with satisfaction while other four dimensions tangibles, assurance, responsiveness and reliability are positively related with the satisfaction. All dimensions have a significant relationship with the satisfaction of customers. The regression was run which indicated that the service quality predicts $15 \%$ change in retention. As this study is conducted on only one service of cellular companies, its scope can be broaden and other services should also be included in the studies. This study is the first one of its nature in Pakistani scenario. This research provides a direction to the decision makers regarding the dimensions of service quality those require high level of attention. This study is restricted to only one service (short messaging service) of cellular companies. Other services might provide different results.

\section{References}

Atalik O., and Arslan M. (2009). A study to Determine the Effects of Customer value on Customer Loyalty in Airline Companies operating: Case of Turkish Air Travelers. International Journal of Business and Management, Vol.4 No.6, pp.154-162

Barnes, James G. (1997). Closeness, Strength, and Satisfaction: Examining the Nature of Relationships Between Providers of Financial Services and Their Retail Customers. Psychology and Marketing, Vol. 14 No. 8, pp.765-790.

Baumann C., Burton S., Elliott G., \& Kehr H.M. (2006). Prediction of attitude and behavioral intentions in retail banking. International Journal of Bank Marketing, Vol 25, No2, pp. 102-116.

Bitner, M.J., and Hubert, A.R. (1994). Encounter satisfaction versus overall satisfaction versus quality. In: Rust, R.T. and Oliver, R.L. (Eds), Service Quality: New Directions in Theory and Practice, Sage Publications, London, pp. 72-94. 
Bolton, R.N., and Drew, J.H. (1991). A longitudinal analysis of the impact of service changes on customer attitudes. Journal of Marketing; 55, pp.1-9.

Brown, S. A., \& Gulycz, M. (2001). Customer relationship management: A strategic imperative in the world of e-business. New York: Wiley.

Cavana, R.Y., Corbett, L.M., and Lo Y.L. (2007). Developing zones of tolerance for managing passenger rail services quality. International Journal of Quality \& Reliability Management, Vol. 24, No.1, pp.7-31.

Chau, V.S., and Kao, Y.Y. (2009). Bridge over troubled water or long and winding road? Gap-5 in airline service quality performance measures. Managing Service Quality, Vol.19, No.1, pp. 106-134.

Chen C.F. (2008). Investigating structural relationship between service quality, perceived value, satisfaction, and behavioral intentions for air passengers: Evidence from Taiwan. Transportation Research Part, A, 42, pp.709-717.

Cöner, A., and Güngör, M.O. (2002). Factors affecting customer loyalty in the competitive Turkish metropolitan retail markets. Journal of American Academy of Business, Vol. 2 No. 1, pp.189-195.

Cronin Jr., Brady M.K., and Hult, G.T.M. (2000). Assessing the effects of quality, value, and customer satisfaction on consumer behavioral intentions in service environments. Journal of Retailing, Vol. 76, No.2, pp.193-218.

Cronin Jr., J.J, and Taylor S.A. (1992). Measuring service quality: A reexamination and extention. Journal of Marketing, Vol. 56, pp.55-68.

Deng, Z., Lu, Y., Wei, K.K., and Zhang, J. (n.d.). Understanding customer satisfaction and loyalty: An empirical study of mobile instant messages in China. International Journal of Information Management, Article in Press.

Emerging WLANs on Incumbent Cellular Service Providers in the U.S. M.J. Services marketing, McGraw-Hill Singapore

Fornell, C. (1992). A national customer satisfaction barometer: the Swedish experience. Journal of Marketing, Vol. 56, pp. 6-21.

Fornell, C., and Wernerfelt, B. (1987). Defensive marketing strategy by customer complaint management: a theoretical analysis. Journal of Marketing Research, Vol. 24, pp. 337-46.

Henkel, D. Houchaime, N. Locatelli, N. Singh, S. Zeithaml, V.A., and Bittner. (2006). The Impact of

Kandampully, J. (1998). Service quality to service loyalty: A relationship which goes beyond customer services. Total Quality Management, Vol.9, No.6, pp.431-443.

Keiningham, T. L., Cooil, B., Aksoy, L., Andreassen, T.W., and Weiner, J. (2007). The value of different customer satisfaction and loyalty metrics in predicting customer retention, recommendation, and share-of-wallet. Managing Service Quality, Vol. 17, No. 4, pp. 361-384.

Kim, M.K., Park, M.C., and Jeong, D.H. (2004). The effects of customer satisfaction and switching barrier on customer loyalty in Korean mobile telecommunication services. Telecommunication Policy.

Lai T.L. (2004). Service Quality and Perceived Value's Impact on Satisfaction Intention and Usage of Short Message Service (SMS). International systems Frontiers, Vol. 6 No. 4, pp. 353-368

Omachonu V., Johnson W.C., \& Onyeaso, G. (2008). An empirical test of the drivers of overall customer satisfaction: evidence from multivariate Granger causality. Journal of Services Marketing, Vol. 22, No. 6, pp. 434-444.

Parasuraman, A., Zeithaml, V.A., and Berry, L.L. (1988). SERVQUAL: A Multiple-Item Scale for Measuring Consumer Perceptions of Service Quality. Journal of Retailing, Vol. 64 No. 1, pp. 12-40.

Reichheld, F.F., and Sasser, W.E. (1990). Zero defection: quality comes to services. Harvard Business Review, Vol. 68 No. 5, pp. 105-11.

Shepherd C.D. (1999). Service quality and the sales force: A tool for competitive advantage. Journal of Personal Selling \& Sales Management, Vol. 19, No. 3, pp.73-82.

Tsoukatos, E., and Rand, G.K. (2006). Path analysis of perceived service quality, satisfaction and loyalty in Greek insurance. Managing Service Quality, Vol. 16 No. 5, pp. 501-19. 
Valdecantos, C. C. (2009). [Onine] http://consultantvalueadded.com/2009/01/12/emergingmarkets-telecom-market-review www.pta.gov.pk

Yu, C. J., Wu, L., Chiao Y., and Tai, H. (2005). Perceived quality, customer satisfaction, and customer loyalty: the case of lexus in Taiwan. Total Quality Management \& Business Excellence, vol. 16 No. 6, pp.707 - 719.

Zeithaml, V.A. (2000). Service quality, profitability, and the economic worth of customers: what we know and what we need to learn. Journal of the Academy of Marketing Science, Vol. 28, No. 1, pp. 67-85.

Table 1. Mean and S.D for service quality, its dimensions and satisfaction

\begin{tabular}{lrr}
\hline & Mean & \multicolumn{1}{c}{$\begin{array}{c}\text { Standard } \\
\text { Deviation }\end{array}$} \\
\hline SERVQUAL & 4.8208 & 0.71827 \\
Tangibles & 5.4003 & 15432 \\
Empathy & 3.3595 & 1.51529 \\
Assurance & 4.852 & 1.20069 \\
Responsiveness & 5.0725 & 1.13993 \\
Reliability & 4.8741 & 1.0582 \\
Retention & 5.3369 & 1.28002 \\
\hline
\end{tabular}

Table 2. Correlation between service quality, its dimensions, and satisfaction

\begin{tabular}{|c|c|c|c|c|c|c|c|}
\hline & & SERVQUAL & Tangibles & Empathy & Assurance & Responsiveness & Reliability \\
\hline \multirow[t]{4}{*}{ Tangibles } & Pearson & & & & & & \\
\hline & Correlation & $.438^{* *}$ & & & & & \\
\hline & Sig. (2-tailed) & & & & & & \\
\hline & & 0 & & & & & \\
\hline \multirow[t]{4}{*}{ Empathy } & Pearson & & & & & & \\
\hline & Correlation & -0.058 & -0.086 & & & & \\
\hline & Sig. (2-tailed) & & & & & & \\
\hline & & 0.29 & 0.118 & & & & \\
\hline \multirow[t]{4}{*}{ Assurance } & Pearson & & & & & & \\
\hline & Correlation & $.705^{* *}$ & $.145^{* *}$ & $-.253^{* *}$ & & & \\
\hline & Sig. (2-tailed) & & & & & & \\
\hline & & 0 & 0.008 & 0 & & & \\
\hline \multirow[t]{4}{*}{ Responsiveness } & Pearson & & & & & & \\
\hline & Correlation & $.860^{* *}$ & $.241^{* *}$ & $-.323^{* *}$ & $.539^{* *}$ & & \\
\hline & Sig. (2-tailed) & & & & & & \\
\hline & & 0 & 0 & 0 & 0 & & \\
\hline \multirow[t]{4}{*}{ Reliability } & Pearson & & & & & & \\
\hline & Correlation & $.705^{* *}$ & $.258^{* *}$ & $-.119^{*}$ & $.394^{* *}$ & $.479^{* *}$ & \\
\hline & Sig. (2-tailed) & & & & & & \\
\hline & & 0 & 0 & 0.03 & 0 & 0 & \\
\hline \multirow[t]{4}{*}{ Retention } & Pearson & & & & & & \\
\hline & Correlation & $.394^{* *}$ & $.190^{* *}$ & $-.248^{* *}$ & $.359^{* *}$ & $.381^{* *}$ & $.297^{* *}$ \\
\hline & Sig. (2-tailed) & & & & & & \\
\hline & & 0 & 0 & 0 & 0 & 0 & 0 \\
\hline
\end{tabular}


Table 3. Regression Analysis (dependant variable 'satisfaction')

\begin{tabular}{ll}
\hline Regression & 0.394 \\
$\mathrm{R}^{2}$ & 0.156 \\
Adjusted $\mathrm{R}^{2}$ & 0.153 \\
& \\
Standard Error & 1.178
\end{tabular}

Table 4. Regression Analysis

\begin{tabular}{llll}
\hline Beta & S.E for Beta & T & Sig. \\
\hline 0.703 & 0.09 & 7.785 & 0 \\
\hline
\end{tabular}

Dependant variable, satisfaction

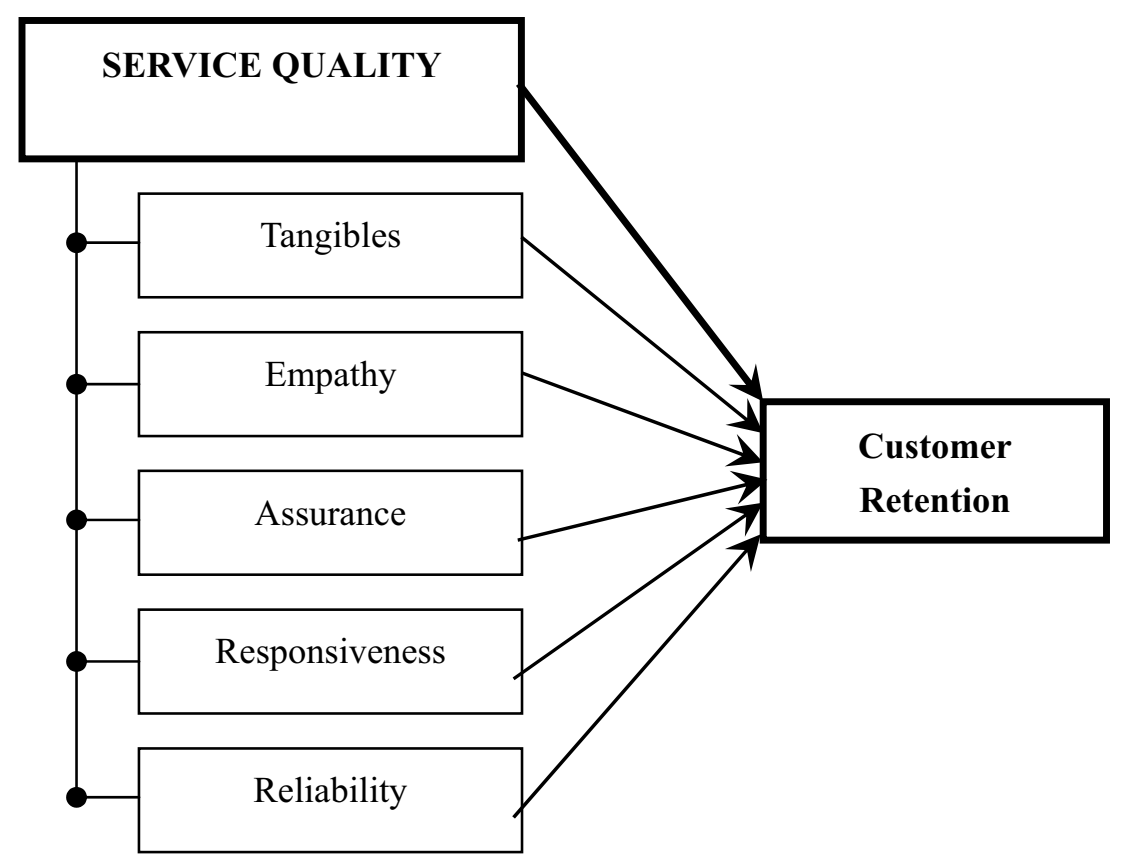

Figure 1. Research Model 